\title{
ETHNOGRAPHY AND MATIJA MAJAR
}

JURIJ FIKFAK

This article examines the research issues and personal problems faced by Matija Majar (a.k.a. Ziljski), one of the most important collectors of folk culture material in the mid-nineteenth century, his place among other researchers, his intentions, and, not least of all, the reception of his work among his contemporaries. Keywords: Matija Majar, ethnography, folk culture, philology.
$V$ članku avtor obravnava raziskovalne dileme Matija Majarja Ziljskega, enega najpomembnejših zbiralcev sestavin ljudske kulture sredi 19. stoletja, njegovo mesto med drugimi raziskovalci in njegove namere, nenazadnje tudi recepcijo njegovega dela pri sodobnikih.

Ključne besede: Matija Majar, narodopisje, ljudska kultura, filologija.

The appearance and the culture of Others - those that are unknown and differenthave always attracted attention. The discipline that strove to discover, define, and study these Others developed in Europe in the late eighteenth and early nineteenth centuries under various names, but mostly as ethnography (Germ. Volkskunde or Völkerkunde). However, the motives for the discipline's development were diverse. On the one hand, they concerned the traveler's view of exotic cultures abroad in non-European countries or, in one's own country, the view of the "uncivilized" layers of the population. An important enlightenment motive stimulated by the state was registration, not only of land and property, but also of the various cultures and layers of the population. This motive was typical of the Habsburg Monarchy, as well as the Russian Empire. Johann Gottfried Herder in particular roused interest in the culture of the peasant population, which was then used to prove constitutive Germanic or Slavic ethnic elements in the distant past. Diverse motives stood for diverse views, emphases, and the use of research; on the one hand, there were motives of statecraft to govern the country as rationally and practically as possible (Lindenfeld 1997). This view included all layers of society, which were or had to be at the service of the state. On the other hand, research stimulated people's self-awareness of their special ethnic identity and led to national awaken-

1 This article is revised (mostly phrasing, but also content to some extent) from "Narodopisje in Matija Majar" (Ethnography and Matija Majar; in B. Škafar Rogelj (ed.) Razstava Slovani Evrope. Musée de Cinquantanaire, Brussels 2008. The Slovene contribution. Loka pri Mengšu: Forum slovanskih kultur, 2008, pp. 13-47.). 
ing; this particular view, which prevailed among the European nations and intellectuals at the turn of the nineteenth century, reveals ethnicity as a fundamental and constitutive element. The prevailing ethnocentric views and the search for a specific identity highlighted the need for self-definition and self-determination-the autonomy of an identity consists of demarcation from others.

It is within this framework that ethnographical research emerged in Slovenia as well, from 1788, when the first volume of Anton Tomaž Linhart's Versuch einer Geschichte von Krain und der übrigen Länder der südlichen Slaven Österreichs (I - 1788; II - 1791 (Attempt at a History of Carniola) was published (Linhart 1981), to the publication of the Einleitung in die slavische Literaturgeschichte (Introduction to Slavic Literary History; $\left(1874^{1} ; 1887^{2}\right)$ by Gregor Krek and Karl Štrekelj’s Prošnja za narodno blago (Appeal for Collecting Folk Traditions; 1887), and ethnography/ethnology established itself as an important means and form of identifying a nation's own culture. It is typical of the discipline's development that it occurred and articulated itself principally through learning about rural folk cultures, unknown to the mainly bourgeois collectors and researchers of the time. This was when transcribing local and regional cultural practices turned folk culture and some of its most visible and fascinating elements (e.g., songs, tales, feast days, costumes, etc.) into essential elements of national identity. In their search for evidence on the historical value of everything Slovenian in the family of European cultures, collectors and researchers turned to folk culture and put it on a pedestal. Based on the findings, ideas, and initiatives of Herder, the Grimm brothers, the Slavic thinkers Ján Kollár, Pavel Jozef Šafárik, František Ladislav Čelakovský, and others, folk and folk culture provided to researchers in Slovenia what the history of the people and nobility failed to offer within the framework of contemporary knowledge. This roughly summarizes the image provided by the history of ethnography/ethnology (Kotnik 1944; Novak 1986) and the survey of motives for turning to folk culture and reasons for ethnographical activities in the first half and middle of the nineteenth century (Fikfak 1999).

Some of the outstanding collectors and researchers of folk culture in this period were oriented in particular towards collecting folk traditions: Jožef Rudež, Andrej Smole, Emil Korytko (Novak 1972), and Stanko Vraz (Novak 1986) in the first half of the nineteenth century, and Ivan Navratil, Matija Valjavec, and others in the mid-nineteenth century. Other collectors and researchers were more oriented towards transcribing local and regional identities as part of a statecraft concept unrelated to the production of national identity, such as Rudolf Puff (Puff 1999). Unfortunately, the Goethe series launched by Archduke Johann, which included all the Slovenian places in Styria (Kuret 1985), and other activities (Kuret 1979) focusing on the Slovenian part of Styria, were not published. The division within ethnography/ethnology itself occurred because of the diverse orientations, either within a statecraft concept, financially supported by the state, or within a nation-building or nation-affirming concept, in which 
all activities had to be financed through private means and often against the will of the state or its administration. Among other things, this is illustrated by Korytko's difficulties with the introduction to the first volume of the collection Şlovénşke péşmi krajnskiga naróda (Slovenian Songs of the Carniolan Nation; cf. Novak 1972). In addition to the difficulties Bleiweis had with publishing Kmetijfke in rokodélfke novize (Farmers' and Craftsmen's News), the newspaper that made room for the Slovenian language in 1843, this revealed the reluctance of the authorities to allow production in the local language. Within the framework of these two concepts, which perceived folk culture from different viewpoints, two options later developed, two scholarly disciplines: the ethnology mainly derived from the statecraft concept, based on geography, and folklore studies mainly from the concept of national affirmation, based on philology.

A second decisive break occurred when ethnographical activities_-or the options to carry out these activities — split into professional and amateur activities. This break between the professional and amateur concepts of collecting and researching folk traditions occurred in the 1830s and was especially due to Emil Korytko (1813-1839) and Stanko Vraz (1810-1851), who published the most significant works of the period. Their approach is characterized by principles of folklore studies, evident from Korytko's programmatic texts, as well as from Vraz's preface to his collection of songs and correspondence. Korytko, who was by education and "horizon a Polish ethnographer beginner" (Grafenauer 1925-1932), lived in Slovenia for a short time, only two years, and most of this within Prešeren's literary circle. In addition to his appeal to all lovers of folk traditions (Illyrisches Blatt, 23 June 1938), he published his fundamental treatise or instructions on how to collect abroad shortly before his death (in the Prague journal Ost und West) (cf. Novak 1986); his collection Şlovénşke péşmi krajnskiga naróda (Slovenian Songs of the Carniolan Nation) was published posthumously (1839-1844). Stanko Vraz certainly had the greatest influence on Slovenian collectors and researchers because of his publications in Slovenian and Croatian, as well as his extensive correspondence, particularly in the Illyrian movement, to which some important figures belonged, and last but not least because of the need to distinguish their own concepts of collecting and researching from those of Emile Korytko. In his articles, letters, and the collection Narodne pěsni ilirske (Illyrian Folk Songs; 1839), Vraz directed other collectors how to transcribe songs and drew their attention to certain types of songs and other cultural elements.

Jakob Volčič (cf. Fikfak 1984, 1988) and Matija Majar certainly were the important members of Vraz's "school" of collecting folk traditions. They were both priests and collected material in the places where they served; Volčič collected important material (songs, proverbs, prose, customs, and traditions) especially on the southwestern fringes of Slovenian territory, mostly in Croatian Istria. Matija Majar focused in collecting material, chiefly folk songs (in the songbook Pesmarica cerkevna (Church Hymnal), published in Vraz's collections), in particular on the area of the Slovenian linguistic 
border (i.e., the northwestern area, extending from Carinthia to Venetian Slovenia, where he served as a priest for most of this time). This article principally deals with his articles, about a dozen, ${ }^{2}$ which he primarily published in Novice and Slovenska bcela, and in which he presented individual elements of folk culture in Slovenia. His most important articles are the preface to his collection of folk songs (1846), in which he explains some rules for transcription; two articles in Kolo: a travel report about western Slovenia (1847b), and a description of mythology in Carinthia (1847a); his descriptions of Slovenian folk customs and traditions in Slovenska bcela (1851); and, on the other hand, his programmatic articles in the paper Novice $(1844,1845,1848,1858$, 1865), which have two purposes: to awaken and shape ethnic consciousness and, simultaneously, educational purposes as part of an enlightened perception of the world.

\section{MATIJA MAJAR'S POTENTIALS AND LIMITS AS AN ETHNOGRAPHER}

If one tries to establish which spiritual circles Matija Majar belonged to, or which ethnic or otherwise established layer of the population, two questions are of prime significance: which scholarly circle acknowledged him as an expert and dedicated corresponding interest to him, and how he presented his collection and research work in articles and letters to other people. This concerns the question of whether Majar had the option to be an ethnographer. To establish Majar's significance within Slavic philology, which included ethnography or ethnology at the time, it suffices to look at the index of names in the following three works: Jagićs (1876) and Pastrnek's (1892) bibliographies of Slavic philology, published in the anthology Archiv für slavische Philologie (Archive of Slavic Philology), and in Gregor Krek's books; for example, in the second edition of Einleitung in die slavische Literaturgeschichte (Introduction to Slavic Literary History; 1887). Among them, Krek was certainly the most knowledgeable about Majar's work because for some time he was responsible for the publication of the collection(s) of Slovenian folk songs; the greatest part of this material was indeed collected by Stanko Vraz, and Matija Majar supplied him with many songs.

What did Majar publish that was worth mentioning in one of these bibliographies or surveys? His most important ethnographical text is probably the unpublished description and public presentation of a Zilja/Gail Valley wedding, including the costumes and wedding cart, which earned him much praise and recognition from Russian scholars-Lavrovsky, Pogodin, Popov, Raevsky and others-at the Slavic Exhibition in Moscow in 1867. In his survey of ethnography in the 1930s, Speranski accorded him an intermediate status between collector and researcher, based on his contribution to this exhibition (see Čurkina 1974: 128-133). Among the other reasons for his

2 See the list of Majar's texts at the end of this article. 
inclusion was another field in which Majar was very active: his efforts (which were also grammar-oriented) towards a common Slavic language and his publishing activities with the journal Slavjan (1872-1875).

Majar's name does not appear in these bibliographies and there may be several reasons for its absence. First of all, as an increasingly established discipline, philology focused on linguistics and literary history in the second half of the nineteenth century. Second, the gap between the various trends at the universities finally created the new discipline of ethnology (see Jacobeit et al. 1994; Bockhorn 1994) under various names (e.g., ethnography or anthropology), which started to demarcate itself from philology. The creation of a special discipline was supported by a range of ethnological, ethnographic, and anthropological societies. However, all this happened only in the late nineteenth century.

Renowned Slovenian scholars - professors at the universities of Graz and Vienna-played an important role in this process and some were instrumental to the discipline’s development (Fran Miklošič, Gregor Krek, Karel Štrekelj, and Matija Murko). They too determined how (in)significant Matija Majar was by not mentioning him in either field: not in his Slavic and grammar-oriented field ${ }^{3}$ including Slavjan, nor in his ethnographical field, including collections and exhibitions. The bibliographies by Jagić and Pastrnek suggest that the Slovenian scholars themselves supplied the compilers with the data on the most important publications in Slovenian philology. Their comments and selection determined who was a scholar and who was not. ${ }^{4}$

An opinion that should be reflected on is Speranski's, who wrote that "by his methods" Majar "belonged to the methodologists of the eighteenth century and that he even adapted acquisitions from the first half of the nineteenth century to these methods" (Črkina 1974: 130). Research has shown that Slovenian collectors and writers of the period indirectly accepted Grimm's school and its rules of transcription, and that they mainly drew on and were inspired by Stanko Vraz and Vuk Karadžić. A typical example is in the instructions "How to transcribe a folk song" in Slovenska bčela (Janežič 1851), where among the models for collecting and transcribing only Slavic names are mentioned, and first of all Stanko Vraz and Vuk Karadžić in particular. ${ }^{5}$ However, another aspect should be mentioned here: Majar's self-reflection and self-presentation to the world around him. In his report on his travels around Venetian Slovenia he writes:

I was thinking to myself: "So you're going to Resia, but what are you going to do there? You'll arrive there after the hay harvest and the grape

3 Miklošič and Levstik rejected Majar’s linguistic concepts (see Slovenski biografski leksikon (SBL), Majar, Matija, SBL: 18).

4 The researchers and collectors mentioned include Matija Valjavec and Ivan Navratil.

5 Other collectors of songs mentioned are Kirsha Danilov, Ivan Petrovich Sakhorov, Ivan Snegirev, Nikolai Tsertelev, Mikhail Aleksandrovich Maksimovich, Ján Kollár, František Ladislav Čelakovský, Wacław Michał Zaleski, and Kazimierz Władysław Wójcicki (Janežič 1851: 126). 
harvest." And I'd say that I was right in not going there because Professor Izmail Sreznevsky harvested the hay, and you harvested the grapes. It is true that no field or vineyard is ever harvested so thoroughly that there are no gleanings left. But for gleaning one needs sharper and healthier eyes than mine. (Majar 1847b: 21)

Majar obviously saw and presented his work largely as auxiliary to that of other researchers, who were more important in his view. In his travel report, he comes to the conclusion that if two such important, eminent scholars have carried out ethnographical research in Resia, than there will be hardly anything left to discover. What was left to him was to visit places that researchers of the renown of Vraz or Sreznevsky had not studied and where he might find something new to reveal to the general public. These research self-limitations probably also had a decisive influence at a later time; for example, on his attempts to obtain suitable employment in Russia. In addition to these limitations there are others to consider: the ones Majar used when addressing as many people as possible and mobilizing them for the Slovenian and Slavic ideas. He therefore lowered the professional, transcription level of a published text, and this is most obviously explained in his preface to Pesmarica cerkevna (Church Hymnal), in which he discusses a nearly insoluble dilemma: that songs should not be published only in the dialect of a single village, but at the same time should be preserved exactly the way they were. Matija Majar's work certainly had the biggest impact at the level of amateur reception and research on local ethnic traditions.

That he was himself well aware of the difficulties of literary production and reception is also obvious from his letter to Stanko Vraz:

Whoever wants to help literature on its feet much surround himself with

1. Many living writers and

2. Many living readers. (21 Brezen (probably March, J. F.) 1844)

This means that Slovenian literature needs many active writers and even more active readers. The principal problem was the lack of sources of communication on both sides: there were not enough senders (writers), and not enough addressees (readers). The newspaper Novize was the first to make headway and become the mediator of much ethnographical information in the nineteenth century.

\section{LOYALTY TO THE SOURCE}

It was important to Majar to study folk traditions across all of Slovenian territory, but due to the conditions in which he served he mainly focused on northwestern Slovenia, as confirmed by the information in his song collection Pesmarica cerkevna (Church Hymnal). As part of the ethnographicclassification system, he was especially interested in songs, customs, traditions, and costumes, but less in tales and the like. 
Influenced by his relations with Stanko Vraz and Urban Jarnik, and reading the works of Vuk Karadžić, Matija Majar arrived at the following solutions in his approach to folklore: folklore is precious because it bears witness to old times, and therefore one of the most important values is loyalty to the source; the original form of a tale or song must be preserved as accurately as possible. Majar used the following concept to achieve this loyalty:

I transcribed them (church songs, J. F.) in detail, exactly as people pronounced them. (Majar 1846: viii-ix);

People in Carinthia tell all kinds of stories about the White Women. I publish these things in practically the same way as people tell them. (Majar 1847a: 12)

At this time, phonetic transcription was still part of the wishes to learn about and present a genuine portrait of the people (cf. Janežič 1851) and loyalty to the source was maintained only when the text was meant to be read by intellectuals. The form and appearance of the transcription thus depended on the specific target readers and the medium in which the text was written. In the preface to Pesmarica cerkevna (Church Hymnal), Majar wrote:

If these books were compiled only for educated people, for linguists, then I would have every word printed as it is, and I would leave out the song Tantum ergo, the litanies, and the Way of the Cross, and instead of them include religious folk ballads, and change a lot in the books. But this songbook is meant in particular for Slovenian singers and I therefore had to make sure of two things; first: not to change them in any way, but to leave them the way they are as much as possible; and, second, I had to make sure that they were easy to understand and familiar to all Slovenians, and I therefore could not keep to the dialect of a single village. (Majar 1846: ix-x)

Matija Majar wrote these words in the preface, addressing himself to intellectuals, to scholars, and arguing the need for professional publication; simultaneously, a couple of pages earlier he attempted to interest singers in the book and singing. Because of the final addressee — an active singing public as broad as possible - the dialect form of the songs is uniform; the songs are understandable and clear to the general public. Despite possible criticism, it should be said that adaptation and reconstruction into a language easier to understand was not rare at the time: probably the best-known example is the Grimm brothers, who published tales in standard German, as did many other writers (see Burke 1981). On the one hand, this was done for the benefit of the readers, who did not understand dialect; and, on the other hand, as Peter Burke describes, it was part of intensive efforts to discover the nation and, in Majar's case, to assist in the formation of his own nation. 


\section{THE MORPHOLOGY OF DESCRIPTION}

In one of his letters to Stanko Vraz, Matija Majar writes about the need for a "simple style" in literature and science; that only such a style could set in motion the national movement. Majar's style in his ethnographical texts is marked by the typical plural form and ethnographic present tense, and in cases where a certain form has not been used for a very long time he preferred various forms of the ethnographic past tense.

The oldest Slavic songs, as far as we know-those that have been preserved to the present day-are high dances. They are festively sung, played, and danced under the green linden tree every year, whenever a church's consecration day, a fair, or a church meeting is celebrated in the Zilja /Gail Valley. (Majar 1865: 135)

According to Konrad Köstlin, the ethnographic present tense of a description is the starting point for the formation of a specific image of folk culture. The present tense and the third person plural, which imply this image, prove by their lack of differentiation that the harmonious image - which is mediated statically, immovably, as a frozen event — can still be repeated. In the "present tense" the past, present, and future are cancelled out because it denotes a timeless condition of things (Köstlin 1991; see Fikfak 1999). In the case at hand, this is of course no criticism of Majar's technique because it was the most frequent form of description at the time; I am concerned with the question of what this description technique conveys or leaves out of the text; it is an attempt to reveal the logic of the style principles of the period.

The explicit and often repeated comments ${ }^{6}$ on the age of the songs contrast with the static image at the morphological level:

We have Slovenian folk songs that are one hundred, two hundred, three hundred years old, and even more. The older a song is, the more beautiful it is. You can count on that! If it were not of special beauty, people would have stopped singing it long ago. These songs are important and precious because of their age alone. (Majar 1850: 89)

On the other hand, there is the awareness that these songs are transient; they bear witness to times and people that are disappearing.

We would do well to carefully collect them so that they won't be forgotten, lost, or damaged. (Majar 1846: v)

These songs are our living audio heritage. We would do well to carefully collect these songs so that they won't be forgotten or be lost because then we would search for them and perhaps would not find them anywhere.

That would really be a shame! (Majar 1850: 90)

6 Nearly identically worded in several texts $(1844,1846,1850)$. 
As part of the prevailing methodology of the time, an essential element of any publication prepared by meticulous, ethnographically oriented collectors and writers was loyalty to what was sung or sold, together with information on the place of performance. However, these data are isolated and limited to some phenomena of folk tradition; indeed, almost exclusively to songs.

\section{THE COLLECTOR AS RESEARCHER AND HIS INFORMANT}

Of all the issues related to research, one of the most important certainly concerns the communication between researcher and informant. How did Majar approach his informants to obtain the desired information? In a letter to Stanko Vraz, ${ }^{7}$ he describes the difficult position of a stranger, especially a priest, in collecting folk traditions:

It's hard for a priest to collect folk songs-people don't know why and wonder; it would be easier if people were familiar with me. (30 January 1843 )

This is one of the reasons why the songs and tales are selected: because the information a priest had access to depended on his position and reputation with the informants; successful collecting requires a good relationship with the informant.

There are also other difficulties typical of a collector or researcher of the objectivations of folk culture in the nineteenth century. There are psychological ones (of an internal nature): the researcher replaces the image of his childhood, of primary socialization, with that of his secondary socialization - the period when doubt is unavoidable (Berger \& Luckmann 1988: 121-136). There are psychological ones (of an external nature): the world where primary socialization occurred was one environment, whereas that of secondary socialization is a different social and cultural environment; the significant "others" are no longer people from the environment of primary socialization. Another very important interference is education, which Majar saw as a category that obstructed collecting; Stanko Vraz wrote about the insurmountable contrast between townspeople and rural people. His informants saw Majar as a priest and he therefore could not collect love songs.

\section{CONCEPTS OF ETHNOGRAPHICAL ACTIVITY}

It often seems as though the collectors of the period did not have a well-considered concept or solutions, that simply, without any deeper consideration, they collected and studied songs and other traditions. In reality, however, through their questions and lis- 
tening within a relatively stable value structure, the collectors had a decisive and selective influence on the informant's narrative or singing, and they selected what to transcribe and publish. This closed approach to collecting is also very obvious with Majar.

On the one hand, there are the ideas what folk tradition is. However, one should first clarify what the people meant to Majar. In 1858, he defined the people in relation to the upper classes in the article "The Slovenian Upper Classes" in Novice:

The nation is like a tree: the peasants are its roots, the townspeople or generally prosperous people are its trunk and branches, and the upper classes and educated people are its lush leaves; writers and men of letters are the noble fruit of the nation's tree. Lush leaves not only adorn a tree, they also make it grow healthy and strong. If you continuously strip the leaves off a tree, it may yet blossom for another year, if it has strong roots - but in the end it will certainly become stunted, dry up, and die. A nation without nationally conscious upper classes is like a tree without leaves: both are short-lived. (Majar 1858: 195)

This concept of the people/nation is similar to the structure of a living organism in which every segment must perform its function to the extent that the entity can operate, because otherwise the people is doomed to decline. The metaphor of a tree, also used by Ján Kollár, presents life as a harmonious whole of interdependent and interwoven elements, and Majar therefore saw the peasant and the intellectuals as two non-competing and incomparable segments of the whole because both had to perform their own tasks.

But who is the carrier of folk tradition? From his travel report (Majar 1847b) and description of Slovenian customs in Slovenski običaji (Slovenian Folk Customs; Majar 1851), it is obvious that in such a structure and relationship between town and countryside the people in the countryside are attributed a special role because they are the carriers of tradition. One can find further determination in the ethnic identity of the carrier of folk tradition. His "subject" is Slovenian folk tradition, the Slovenians - the Slovenian people with all the aforementioned qualities, not their opposites, who are foreigners, Germans, and have no understanding whatsoever for anything Slovenian or Slavic ("slavjansko"). Because he served on the linguistic border, Majar was particularly sensitive to Germanization trends and any shift southwards of this border. A third feature is the difference between the higher, "artificial" culture of the elite, the intellectuals, and the "genuine/unadulterated" culture of the peasants, the rural inhabitants: what is "folk" is simple, durable, beautiful, and understandable to everybody. The result of these opposites is the Slovenian people as the carriers of the oldest, simplest, and most beautiful songs and tales; they, the "ordinary" people, are an irreplaceable segment of the nation's living tree.

What are Majar's specific aspects in the description of folk culture and collecting folk traditions? At which levels does he attempt to suggest a differentiated image of the 
world? What questions or conflicts did he describe and where and why did he try to describe a harmonious image of the world? Majar largely recorded an undifferentiated image of the world that is evident from his descriptions of the Slovenians and their folk culture. He is also highly affirmative because his image of the Slovenians and their folk character is highly positive throughout:

The Slovenian is pious, of keen mind, good-hearted, and cheerful. He was like that in the old days and that is what he is like today. Everyone can see this for himself when he has dealings with our Slovenians.

(Majar 1844: 136)

Majar's choice of words shape the image of a pious and good-hearted Slovenian, who loves his country. The typical words are pious, clever, Slavjan 'Slav', good-hearted, nationally conscious, and so on. In this way, too, Majar provided a remarkably positive image of rural people, but he also warned them that the old songs had a shine that should not be changed or corrected in any way. He emphasized the beauty of the old songs, but simultaneously suggested that they, and with them folk culture, was disappearing.

These songs are full of piety and lyrical beauty, they are living memories and clearly show us and bear witness to the pious heart and keen mind of our Slovenians. We would do well to carefully collect them so that they will not be forgotten, lost, or damaged. (Majar 1846: v)

It is the duty of every Slovenian, every Slav, to preserve these witnesses of our culture: And every true Slav wants to protect and preserve these things . . (Majar 1846: viii)

\section{SLAVIC MUTUALITY}

Majar saw options for preserving and inspiring Slovenian character and its culture only in the broader Slavic context. He stated this opinion very clearly in a letter to Stanko Vraz, when he answered his question "How and on what will the Slavic peoples have to agree? (Žabnice/Camporosso, 22 Nov. 1848):

In my opinion it is absolutely necessary that all the Slavs of our empire adhere to two rules:

1. There is but one Slavic nation in our empire; we must never confront the government and the other nations of our country divided by peoples_that would mean our ruin,

2. The Slavic peoples in Austria are: 1. Slovenians, 2. Croats, 3. Serbs, 4. Czechs, 5. Moravians, 6. Slovaks, 7. Poles, 8. Ruthenians-no more, no less - All these people are equal and have the same rights.

This is why Majar sought so long for options and among other things devoted himself to a new Slavic language that could be used to communicate by Slavic intellectuals. 


\section{MAJAR: NATIONAL ACTIVIST, JOURNALIST, ETHNOGRAPHER, GRAMMARIAN}

Matija Majar's work is very important to Slovenian ethnology because it expressed the issues of the Slovenian language from its fringe areas. In his time, Majar was considered a collector that was familiar with and observed the transcription rules from the first half of the nineteenth century. Based on Ján Kollár's idea of "Slavic mutuality," he created and participated in a network of close connections between Slovenians, Croats, Serbs, Czechs, Slovaks, and Russians. To Majar, the greatest success that resulted from his participation in the network was the Slavic Exhibition in Moscow in 1867. Because he lived on the Slovenian linguistic border, he was particularly sensitive to the strong Germanization influences and therefore sought Slavic unity, but he simultaneously objected to the dominant role of Russian in Slavic territory. He acknowledged the different nature of every small nation (including the Slovenian nation) and therefore explored a Slavic "Esperanto." He imagined the nation as a living, harmonious organism of intellectuals, researching the life of the ordinary people, who perpetuate that life, proving its roots and age.

Matija Majar perceived all his intentions, his pastoral, national-awakening, collection, and research activities in the sense and function of the slogan "All for the benefit and happiness of the people." Among other activities, he also saw ethnography as a means to prove that Slovenian character and Slovenian folk culture were indispensable values.

Majar's publishing activities concluded with the periodical Slavjan, which he published at his own expense while he suffered increasing problems with his vision. He was active in two reference networks, which I would paradigmatically denote as the Illyrian Movement and "Slavic Mutuality." The death of Stanko Vraz, who was the main protagonist of the Illyrian Movement in Slovenia, largely disintegrated the first of these two networks, and then Majar started to explore the options for Slavic mutuality and for his own publishing activities as well as scholarly affirmation in Russian professional and research circles. ${ }^{8}$

Nineteenth-century researchers usually encountered difficulties because of the basic ambivalence of their aspirations. They studied the culture of their own people amid a host of awakening nations because they also wanted to affirm themselves as part of their people. They sought a positive (self-)image in folk culture and largely found it, but they also found the opposite as they encountered the gap and frequent misapprehensions between civilized, educated people and uneducated, "plain" or "ordinary" folk. Majar wished the latter to become civilized while preserving their "plain" nature." This ambivalence is typical of Majar, too, and on his travels across western Slovenia he wrote:

8 He sent his collection of folk songs, which were part of Vraz's legacy and were to be published by Slovenska matica (Slovenian Society), to Moscow (see SBL, 16). 
Wherever I would meet one of these simple people, he would greet me heartily. And when I felt like it, I would exchange a few words with him and then take to the road again, but he would keep standing there, watching after me amiably and shouting good wishes until I disappeared from his sight: "May God give bring you happiness! May God give you health! May God protect you wherever you go!"-Good people! May God give happiness and progress to you! May God protect you on your way when you set out on the road to education! May God clear your eyes so that you will see the right path and not slip on it! May God inspire you with the spirit of His wisdom so that you will make the right decisions, that you will not waste your own gold on the gilded things of foreigners, blinded by their outer shine! ... And now I say goodbye and may God help you! (Majar 1847b: 36-37)

The framework of his time and environment, as well as his personal decision in favor of other priorities, did not allow him to carry out ethnographical and scholarly work to the same extent as Stanko Vraz, Izmail Sreznevsky, and others. He chose different fields of activity; over the course of four decades, he was particularly successful in the national awakening movement with his idea of and engagement for a United Slovenia. The Slovenians will always consider this his greatest achievement.

\section{MAJAR, THE SLAVIC EXHIBITION, AND INTERCULTURAL DIALOGUE}

In attempting an evaluation of his ethnographical work, one must consider Speranski's opinion that Majar was something between a collector and researcher. At the same time, it is necessary to reject the idea that Majar's work belonged to the methodology of the eighteenth century. In his collection work Majar certainly adhered to the findings of the early nineteenth century, introduced to Slovenia by Urban Jarnik and Stanko Vraz. That some of his concepts were more refined than those of other ethnographers is evident from his contribution to the Slavic Exhibition in 1867. ${ }^{9}$ It is true that in the concept of his presentation of the Slovenian Zilja/Gail Valley folk culture he reconstructed the costumes, as others did, in order to emphasize their importance and special features. On the other hand, however, he diverged from other researchers in his reconstruction of the ritual practice's image, in which the costumes are an important factor. Whereas other nations presented individual costumes, Majar strove to show their function because he reconstructed the image of a

9 Teodor Domej discovered the collection that Matija Majar sent to the 1867 exhibition at the Russian Museum of Ethnography in Saint Petersburg. The crafted material was inventoried and partially restored for an exhibition in Saint Petersburg in 2007 and in Brussels in 2008. 
Crate in which Majar's shipment to Moscow is stored (all photos by J. Fikfak, 2006).

Entries in register and descriptions of material.

Cataloging cards.
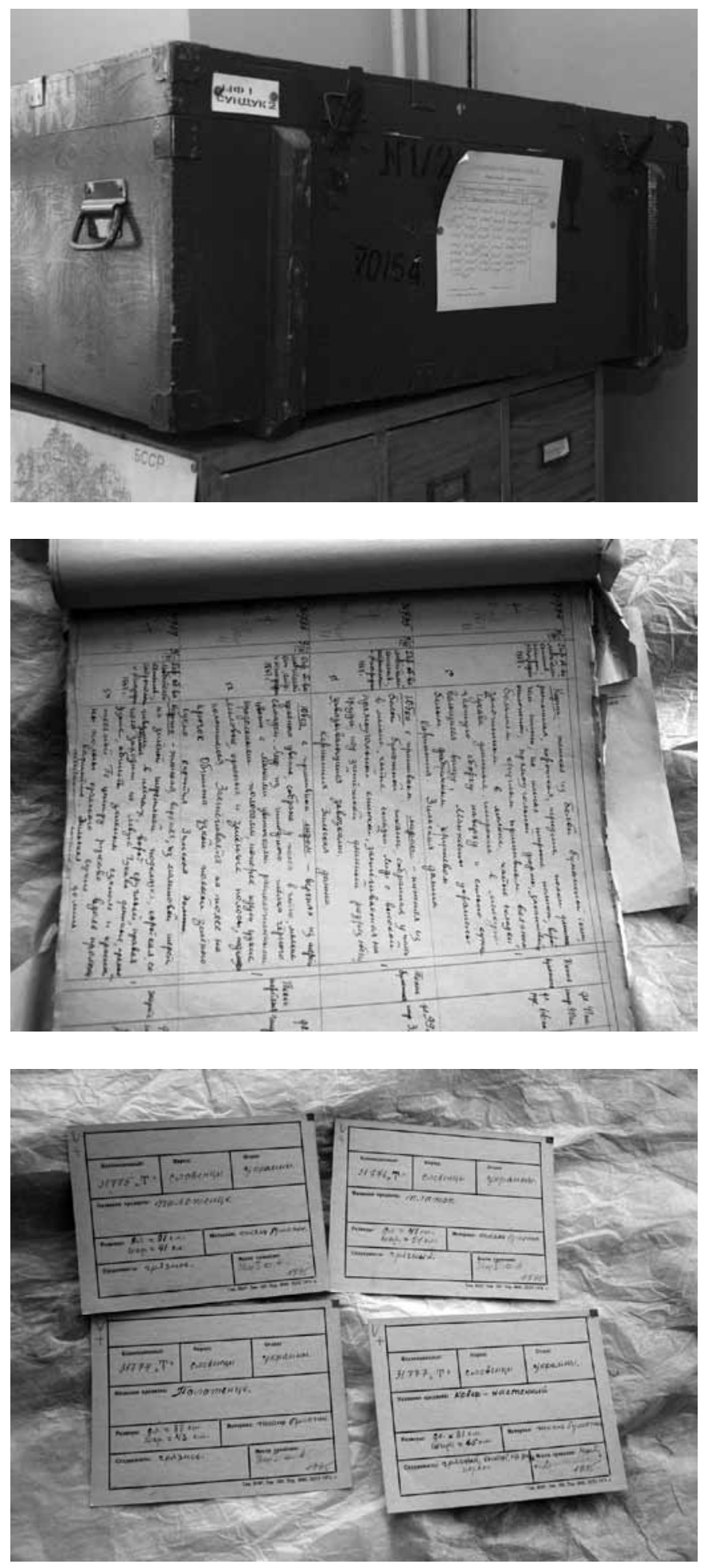
ritual practice: a Zilja/Gail Valley wedding, in which the costumes are an important and active factor demarcating ethnic identity (see also Žagar 2008; Simetinger and Knific n. d.).

At the exhibition in Saint Petersburg in November 2007, two original concepts from the 1867 exhibition were presented. The Russian concept included all the major peoples of Russia in the exhibition and thus followed the statecraft, enlightenment concept of ethnography, which dictates that all the layers of the population should be registered and presented This emphasis was further enhanced, contextualized by the relief of the peoples of the Soviet Union in the marble hall of the Ethnographic Museum in Saint Petersburg, which dates from the 1920s. With the other Slavic nations, the 2007 exhibition emphasized the national representative aspect of the exhibits they had sent; these nations had largely lived in political systems (e.g., in the Austro-Hungarian Monarchy or the Ottoman Empire) where the representatives of the Slavic cultures sought social recognition. Considering this aspect, the effort of these ethnologists especially focused on ethnic and national emphases; many costumes were reconstructed or purpose-made for the needs of the great Slavic Exhibition in Moscow. Some emphases by Russian ethnographers (e.g., Speranski) show little understanding of the special role ethnologists had elsewhere. Today we can describe this need for differentiation not only as a national constitutive element, but also as a constitutive element of any identity or culture. The wish for multifaceted affiliations is simultaneously a wish for finer distinctions and borders that constitute individual affiliation. The path to real intercultural dialogue can open up only then, when the borders and cultures are constituted, just as the autonomous worlds of cultures and identities are established and sovereign.

\section{REFERENCES}

Berger, Peter and Thomas Luckmann

1988 Družbena konstrukcija realnosti. Ljubljana.

Bockhorn, Olaf

1994 „Volkskundliche Quellströme“ in Wien. Anthropo- und Philologie, Ethno- und Geographie. Jacobeit, Wolfgang et al. (eds.), Völkische Wissenschaft, 417-424.

Burke, Peter

1981 Helden, Schurken und Narren. Europäische Volkskultur in der frühen Neuzeit. München.

Cvirn, Janez

2001 Der Alpan-Adria-Raum 1750 bis 1815. In: Moritsch, Andreas (ed.), Alpen-Adria. Zur Geschichte einer Region. Klagenfurt/Celovec, Ljubljana/Laibach, Wien/Dunaj, 293-318.

Čurkina, Iskra V.

1974 Matija Majar - Ziljski. Ljubljana: SAZU (Razprave SAZU VIII/2), 75-193.

Fikfak, Jurij

1984 Iz etnološkega in folklorističnega dela Jakoba Volčiča, objavljenega v Novicah 1851-1881. Etnološka tribina (Zagreb) 13-14 (6-7): 97-105. 
1999 Ljudstvo mora spoznati sebe. Podobe narodopisja v drugi pol. 19. stoletja. Ljubljana.

Fikfak, Jurij (ed.)

1988 Jakob Volčič in njegovo delo. Zbornik prispevkov in gradiva = Jakov Volčić i njegovo djelo, Zbornik priloga i grade. Pazin in Ljubljana.

Ginzburg, Carlo

1988 Spurensicherungen. Über verborgene Geschichte, Kunst und soziales Gedächtnis. München.

Grafenauer, Ivan

1925-1932 Korytko Emil. In: Cankar, Iz- and F. K. Lukman (eds.), Slovenski biografski leksikon. Ljubljana, 521-523.

Jacobeit, Wolfgang, Hanjost Lixfeld, and Olaf Bockhorn (Eds.)

1994 Völkische Wissenschaft. Wien.

Jagić, Vatroslav

1876 Bibliographische Übersicht der Erscheinungen auf dem Gebiete der slavischen Philologie und Alterthumskunde seit dem Jahre 1870. Archiv fuer slavische Philologie (Berlin) 1.

Janežič, Anton

1851 Kako se morajo zapisovati narodne pesni. Slovenska bčela (Celovec) 2 (1): 126.

Köstlin, Konrad

1991 Der Alltag und das ethnographische Präsens. Ethnologia Europaea 1: 71-86.

Kotnik, Fran

1944 Pregled slovenskega narodopisja. In: Ložar, Rajko (ed.), Narodopisje Slovencev I. Ljubljana, 21-52.

Korytko, Emil

1839-1844 Slovenske pesmi krajnskiga naróda. Ljubljana. [zv. 1. - 1839; 2. - 1840; 3. - 1841; 4. - 1841; 5. - 1844.]

Krek, Gregor

1873 Nekoliko opazek o izdaji slovenskih narodnih pesni. Slovenski narod IV. Listki (Ljubljana): 96140.

$1887^{2}$ Einleitung in die slavische Literaturgeschichte. Wien.

Kuret, Niko

1979 Slovensko narodopisno gradivo v zamejskih zbirkah. Slovenski etnograf (Ljubljana) 30: 37-55.

1985 Slovensko Štajersko pred marčno revolucijo 1848. Topografski podatki po odgovorih na vprašalnice nadvojvode Janeza (1818) in Georga Götha (1842). Prvi del.1. snopič. Ljubljana: SAZU (Gradivo za narodopisje Slovencev; 3).

Lindenfeld, David F.

1997 The practical imagination: the German sciences of state in the nineteenth century. Chicago: The University of Chicago Press.

Linhart, Anton T.

1981 Poskus zgodovine Kranjske in ostalih dežel južnih Slovanov Avstrije. Ljubljana. (Trans.: Versuch einer Geschichte von Krain und übrigen Ländern der südlichen Slaven Oesterreichs. 1788, 1791).

Majar, Matija

1844 Nekaj od Slovencov. Iz Koroškiga. Novice (Ljubljana) 2: 136, 138-139, 151-152, 155-156, 159, $172,175-176$.

1845 Slovenske besede. Novice (Ljubljana) 3: 155-156, 159-160, 163, 170-171, 175, 178-179, 183, 186.

1846 Pesmarica cerkevna, ali svete pesme, ki jih pojo ilirski Slovenci na Štajerskim, Kranjskim, Koroškim, Goriškim in Benatskim in nektere molitvice, litanije in svet križoven pot, zbral in na svet izdal Matia Majer, kaplan pri stolni cerkvi v Celovcu. Celovec. 
1847a Vile i šta od njih znade narod slovenski u Koruškoj. Kolo (Zagreb) IV: 9-18.

1847 b Putovanje po Goričkom, Mletačkom i Tarštjanskom. Kolo (Zagreb) VI: 20-37.

1848 Slava Bogu na višavah. Novice (Ljubljana) 6: 50.

1850 Narodove pesni. Slovenska bčela (Ljubljana)1 89-93.

1851 Slovenski običaji. Slovenska bčela (Celovec) 2 (1): 10-12, 27-28, 42-44, 58-60, 74-76, 90-92, 105-107, 121-122, 183-187.

1858 Slovenska gospoda. Novice (Ljubljana)16: 194-197.

1865 Visoki raji. Novice (Ljubljana) 23: 135-136.

Moritsch, Andreas (ed.)

1995 Matija Majar Ziljski. Zgodovina brez meja 2. Klagenfurt/Celovec, Ljubljana/Laibach, Wien/ Dunaj.

2001 Dem Nationalstaat entgegen (1848-1914). In: Moritsch, Andreas (ed.), Alpen-Adria. Zur Geschichte einer Region. Klagenfurt/Celovec, Ljubljana/Laibach, Wien/Dunaj, 339-406.

Novak, Vilko

1972 Emila Korytka nemški članki o slovenskem ljudskem izročilu. Traditiones (Ljubljana) 127-52.

1986 Raziskovalci slovenskega življenja. Ljubljana.

Pastrnek, Fran

1892 Bibliographische Uebersicht ueber die slavische Philologie 1876-1891. Verfasst von Dr. Fr. Pastrnek. Zugleich Generalregister zu Archiv Band I-XIII. Berlin, Weidmannsche Buchhandlung. 1892. Archiv für slavische Philologie, Supplement-Band.

Puff, Rudolf G.

1999 Maribor,Njegova okolica, prebivalci in zgodovina. Maribor (Documenta et studia historiae recentioris; 13). (Prevod dela: Marburg in Steiermark, seine Umgebung, Bewohner und Geschichte).

Simetinger, Tomaž and Bojan Knific

n. d. Predstavitev oblačenja Ziljanov leta $1867 v$ St. Peterburgu (http://www.jskd.si/folklorna-dejavnost/ kostumi_folklora/simetinger_knific_predstavitev_st_petersburg.htm).

Speranski, M. N.

1931 K istorii slavjanskoij etnografii. In: Izvestija Akademii nauk SSSR, Otdelenie obščestvennih nauk, 985-1000.

Štrekelj, Karel

1887 Prošnja za narodno blago. Ljubljanski zvon (Ljubljana) 7: 629-632.

Vraz, Stanko

1839 Narodne pesni ilirske, koje se pevaju po Štajerskoj, Kranjskoj, Koruškoj i zapadnoj strani Ugarske. Skupio i na svet izdao Stanko Vraz. Razdelak I. Zagreb.

Žagar, Janja

2008 Med oblačenjem in kostumiranjem. In: Rogelj Škafar, Bojana (ed.) Razstava Slovani Evrope. Musée de Cinquantanaire, Bruselj 2008. The Slovene contribution. Loka pri Mengšu: Forum slovanskih kultur, 49-53.

\section{NARODOPISJE IN MATIJA MAJAR}

Leta 1867, ko so se z uvedbo avstro-ogrskega dualizma razmerja med narodi habsburške monarhije zaostrila, so se vsi vidnejsi predstavniki slovanskih narodov, srečali v Moskvi. $\mathrm{Na}$ veliki slovanski razstavi so razstavili najizrazitejše narodopisne značilnosti slovanskih 
ljudskih kultur. Med razstavljenimi eksponati je posebno pozornost zbudila skupina ziljske ohceti, ki jo je tja poslal Matija Majar, duhovnik s slovenskega jezikovnega obrobja. $V$ prvi polovici 19. stoletja sta se $v$ narodopisju uveljavila dva pogleda na drugo, na tuje. Prvega, razsvetljenskega, je utemeljila država, ki je želela evidentirati zemljišča, premoženje, različne kulture in plasti prebivalstva. V tem, državoznanskem, okviru je na Slovenskem nastala t. i. Göthova serija nadvojvode Janeza, ki je zapisovala lokalno identiteto. $V$ okviru drugega, romantičnega, pa so se pri iskanju dokazov o zgodovinskosti lastnega naroda v evropski družini raziskovalci obrnili $k$ ljudskemu in ga povzdignili na piedestal. Na osnovi spoznanj Herderja, bratov Grimm, Kollárja in drugih slovanskih mislecev so v ljudski kulturi našli germanske ali slovanske konstitutivne narodne elemente - ta partikularni pogled, prevladujoč na prehodu iz 18. v 19. stoletje, je odkril narodno pripadnost kot temeljno določilo.

Recepcijo ljudskega je na Slovenskem sooblikoval tudi Stanko Vraz, ki je z besedili, pismi idr. zbiralcem predpisal načine zapisovanja in usmerjal pozornost na določene vrste pesmi ali drugih kulturnih prvin. Matija Majar se je pri zbiranju gradiva za Vraza osredotočil predvsem na področje jezikovne meje, od Koroške do Benečije. Predstavil je prvine ljudske kulture (bajeslovje, šege) in pravila zapisovanja. Za razstavo v Moskvi je prispeval podrobnejsi opis ziljske ohceti. S programskimi članki pa je dvigal narodno zavest in hkrati vzgajal.

Ker je Majar živel na jezikovnem obrobju, je bil še občutljivejši za germanizacijske vplive. Iskal je slovansko slogo in hkrati snoval možnosti za slovanski "esperanto". Dejaven je bil $v$ dveh mrežah, $v$ ilirskem gibanju in "slovanski vzajemnosti«. Po smrti Vraza, nosilca ilirskega gibanja, je Majar začel iskati možnost slovanske vzajemnosti in svoje uveljavitve $v$ ruskih krogih. Njegov največji uspeh je bila udeležba na razstavi v Moskvi 1867, kjer se je pokazalo, da je bil njegov koncept bolj izdelan kot pri drugih narodopiscih. Tako kakor drugi je za predstavitev slovenske ziljske kulture re-konstruiral noše, da bi poudaril njihov pomen in posebnosti; hkrati jih je pokazal $v$ funkciji z re-konstrukcijo podobe ritualne prakse - ziljske ohceti, $v$ kateri so noše tudi narodno - identitetno razločevalen in tvoren dejavnik.

Matija Majar je vse svoje dušnopastirsko, narodnoprebudno in zbiralsko delo podredil geslu "Vse na korist in srečo svojemu narodu". Narodopisje je razumel kot sredstvo, s katerim bi dokazal, da sta slovenstvo in slovenska ljudska kultura neprecenljivi vrednoti.

Dr. Jurij Fikfak, Institute of Slovenian Ethnology ZRC SAZU, Novi trg 2, SI-Ljubljana, fikfak@zrc-sazu.si 